specialists' training, which would provide student-centeredness, openness, flexibility, mobility, practical orientation and integration, which in the future will enable a specialist to adapt to the changing conditions of professional activity.

The necessity of shifting the emphasis to mastering a foreign language through the integration of professional disciplines and a foreign language through the implementation of content and language integrated learning has been stated. The importance of involving content and language integrated learning has been substantiated.

A number of problems related to the practical implementation of content and language integrated learning in the educational process of technical institutions of higher education have been characterised. There are such problems as insufficient level of English language proficiency by students and teachers of professional disciplines to present educational material in English; difficulties in cooperation between foreign language teachers and teachers of professional disciplines in creating and developing curriculum, syllabus and educational materials; improving English language skills by both students and teachers.

Features of content and language integrated learning in the conditions of training students of engineering and technical majors have been presented. There are such peculiarities as simultaneous mastering of a foreign language and future major (with the help of professionally-oriented disciplines); learning a foreign language as a means for teaching and mastering extralinguistic content of nonlinguistic disciplines by students; authenticity of educational materials; creating an atmosphere of cooperation, trust and empathy; formation of an active personality, ready for self-education, selfdevelopment, self-improvement; interaction of foreign language teachers and teachers of professional disciplines, etc.

Key words: content and language integrated learning (CLIL); interdisciplinary connections; cooperation of teachers of professional disciplines with teachers of foreign languages; models of content and language integrated learning.

\title{
НОРМАТИВНО-ПРАВОВЕ ЗАБЕЗПЕЧЕННЯ ПРОФЕСІЙНОЇ ПІДГОТОВКИ МАЙБУТНІХ ОФІЦЕРІВ ВІЙСЬКОВО-МОРСЬКИХ СИЯ ЗА БОЙОВОЮ АРМІЙСЬКОЮ СИСТЕМОЮ
}

У статті зазначено, що відбувається постійне переформатування професійної підготовки курсантів з метою забезпечення їхніх ефективних дій (бойової діяльності) векстремальних умовах зовнішнвого середовища, за наявності значних фізичних іпсихологічних напружень, наростаючої втоми та інших несприятливих чинників бойової діяльності. Аля організациї високоякісної підготовки курсантів до професійної діяльності засобами Бойової армійської системи провідну роль відіграють основні положення Тимчасової настанови з фізичної підготовки в Збройних Силах України; щорічних директив Генерального штабу Збройних Сил Украйни та відповідних наказів Генерального штабу Збройних Сил України. Бойова армійська система передбачае тактичну, вогневу, фізичну (загальну i спецііальну) підготовку і тактичну медиццину.

*(C) Чернявський O. А.

03 
Окреслено основні положення, які регулюють запровадження бойової армійської системи у процес професійної підготовки майбутніх офіцерів ВМС у закладах вищої військової освіти України. Методологію дослідження становлять основні положення теорії пізнання та такі підходи як акмеологічний, задачний, діяльнісний й взаємодоповнювані методи, зокрема, контент аналіз, узагальнення, вивчення документації. Наукова новизна дослідження полягае вокресленні нормативно-правових основ впровадження бойової армійської системи у професійну підготовку майбутніх офіцерів.

Зроблено висновок, щзо високоякісна підготовка офіцерів тактичного рівня ВійськовоМорських Сил передбачае комплексність та неперервність ї забезпечення, sрунтування на розумінні й усвідомленні мети, завдань і механізмів їх реалізації та методично доцільного забезпечення практичної реалізації кваліфікованими викладачами (інструкторами) з урахуванням положень аналітичних звітів щодо позитивів і недоліків упровадження бойової армійської системи та відповідно до унормовуючих документів.

Ключові слова: Військово-Морські Сили (ВМС); Збройні Сили Украйни (ЗСУ); майбутні офіцери; професійна підготовка; Бойова армійська система

Постановка проблеми. Підготовка фахівців Військово-Морських Сил Збройних Сил України щорічно зазнає змін та реорганізацій, пов'язаних із підвищеними вимогами до професійної підготовки військовослужбовців, які забезпечують безпековий стан країни. 32014 року відбувається постійне переформатування професійної підготовки курсантів з метою забезпечення їхніх ефективних дій (бойової діяльності) «в екстремальних умовах зовнішнього середовища, за наявності значних фізичних і психологічних напружень, наростаючої втоми та інших несприятливих чинників бойової діяльності» $[1 ; 3$, с. 5]. Як слушно зазначають фахівці, «уміння користуватися зброєю і бойовою технікою, знання тактики ведення дій є далеко недостатньою умовою для успішних дій військовослужбовця в бою. Система продуманої фізичної підготовки в значній мірі сприяє підвищенню боєздатності й боєготовності військ, успішності військово-професійного навчання, забезпечуе скорочення термінів і подіпшення якості підготовки військовослужбовців при овододінні різними видами бойової техніки, для забезпечення надійності управління нею в складних умовах. Разом з тим, уміння і навички долати несприятливі чинники, що супроводжують бойову діяльність, потрібно формувати ще до початку бойових дій» $[1 ; 3$, c.5]. Зазначене вимагає переорієнтування військово-прикладної підготовки курсантів на комплексну підготовку 3 усіх напрямів, які забезпечують відповідність вимогам ведення сучасних бойових дій, зокрема і в умовах локальних конфліктів. Саме на окреслення фахової підготовки курсантів, зокрема іi нормативно-правового забезпечення щодо комплексності спрямовано авторську наукову розвідку.

Аналіз досліджень. В Україні підготовка військовослужбовців за Бойовою армійською системою активно здійснюеться з 2015 року відповідно до нормативних документів (директив, наказів тощо), затверджених Генеральним Штабом Збройних Сил України; Методичних напрацювань: Методичні рекомендації з організації підготовки військовослужбовців за Бойовою армійською системою (2020), Методичні рекомендації 3 використання елементів Бойової армійської системи (БАРС) на заняттях з вогневої, тактичної, фізичної підготовки та тактичної медицини (2019), Навчально-методичний посібник «Базові положення та елементи основних видів підготовки за Бойовою армійською системою (БАРС)» (2016); Програм загальновійськової базової підготовки за Бойовою армійською системою, Програм рукопашної підготовки за Бойовою армійською системою (БАРС) та ін. Розробка заходів та аналіз якості підготовки за Бойовою армійською системою здійснюеться відповідно до організаційнометодичних вказівок із впровадження бойової армійської системи (БАРС) в загальну систему підготовки Збройних Сия України. 
Зазначимо фундаторів розробки, адаптації та впровадження БАРС у систему підготовки військовослужбовців України - це, зокрема: І.Ф. Беловодов, О. В. Гуляк, А. В. Гончарук, О. А. Десятка, С. В. Іванов, І.А. Костюшко, В. М. Аивар, А. О. Набока, А. М. Нікітін, I.С. Овчарук, О. М. Ольховий, I. М. Павелко, К. М. Сидорченко, М. В. Тверезовський, С. А. Терентьєв, О. А. Чернявський, В. П. Ягодзінський та ін.

Мета статті полягає в окресленні основних положень, які регулюють запровадження бойової армійської системи у процес професійної підготовки майбутніх офіцерів ВМС у закладах вищої військової освіти України.

Методологію дослідження становдять основні положення теорії пізнання та такі підходи, як акмеологічний, задачний, діяльнісний та взаємодоповнювані методи: контент аналіз, узагальнення, вивчення документації.

Наукова новизна дослідження полягає окресленні нормативно-правових основ упровадження бойової армійської системи у професійну підготовку майбутніх офіцерів ВМС ЗСУ в закладах вищої освіти.

Виклад основного матеріалу. В організації високоякісної підготовки курсантів до професійної діяльності засобами Бойової армійської системи провідну родь відіграють основні подоження Тимчасової настанови з фізичної підготовки в Збройних Силах України, затвердженої наказом Генерального штабу Збройних Сил України від 11 лютого 2014 року № 35; щорічних директив Генерального штабу Збройних Сил України «Про організацію підготовки Збройних Сил України в (із зазначенням року) навчальному році» та відповідних наказів Генерального штабу Збройних Сил України.

Зокрема, Наказом № 468 від 13.12.2019 р. «Про організацію фізичної підготовки у Збройних Силах України в 2020 навчальному році» окреслено, що фізична підготовка є одним з основних предметів підготовки військовослужбовців Збройних Сил України. Відповідно, у вищих військових закладах освіти (за чинною термінологією МОУ та ЗСУ вищі військові навчальні заклади - ВВН3) (військових навчальних підрозділах закладів вищої освіти ВНП ЗВО / ВПН ВНЗ) Пї необхідно спрямувати на розвиток та вдосконалення загальних і спеціальних фізичних якостей, набуття військовоприкладних рухових умінь (відповідно до напрямів підготовки) [4] і досягнення професійно-спрямованої фізичної готовності із забезпеченням належної навчальноматеріальної бази для набуття курсантами відповідних компетентностей та формування професійних навичок із подальшим їх відпрацюванням в умовах, наближених до бойових. Відповідними додатками деталізовано організаційні та змістові аспекти фізичної підготовки, спортивно-масової роботи, проведення спортивних заходів, спартакіад різних груп, змагань, експерименту 3 організації фізичної підготовки у визначених силах (родах) тощо.

Наголосимо, що зазначене стосується не лише курсантів, а й усього особового складу Збройних Сил України. Зокрема, проведення Спартакіади ВМС Збройних Сил України регламентується «Положенням про проведення Спартакіади ВійськовоМорських Сил Збройних Сил України» (із зазначенням року), затвердженим відповідним чином. Змагання передбачають: Воєнізований крос на 3 км зі стрільбою та метанням гранати; Швидкісна і прикладна стрільба (швидкісна стрільба 3 пістолета, 3 автомата, Прикладна стрільба з ПМ (пістолет Макарова), АК (автомат Калашникова); Багатоборство ВСК (військово-спортивної класифікації); футзал; гирьовий спорт; плавання; кульова стрільба; настільний теніс; легкоатлетичний крос; бокс; гребля на шестивесельних морських ялах на 2 км; рукопашний бій; спортивне орієнтування та ін. Зауважимо, що переважна частина зазначеного е складовою Бойової армійської системи, яка передбачає тактичну підготовку, вогневу підготовку, фізичну (загадьну і спеціальну) підготовку і тактичну медицину.

Бойова армійська система (БАРС) являе собою комплексну систему навчання 3 питань тактичної підготовки, рукопашної підготовки, тактичної медицини, вогневої підготовки, гірської підготовки, яка базується на концепції, побудованій на єдиній 
психологічній основі, що дозволяе суттєво підвищити ефективність військовопрофесійної діяльності особового складу.

У 2016 році відповідно рішенню начальника Генерального штабу Головнокомандувача Збройних Сил України від 31.05.2016 № 15021/С у Головному управлінні підготовки Збройних Сил України проведено установчу нараду з упровадження Бойової армійської системи в систему підготовки Збройних Сил України, яка у царині вищої військової освіти передбачала організацію і впровадження таких заходів: уведення (спочатку в освітній процес Військової академії (м. Одеса)) курсів з БАРС тричі на рік упродовж 3-х місяців у кількості до 15 осіб з відповідними змінами у штатному розкладі Військової академії та подальше укомплектування викладацьким складом Національної академії сухопутних військ імені гетьмана П. Сагайдачного випускниками 2016 року Військової академії (м. Одеса) - фахівцями 3 фізичної підготовки та спорту [9] для поширення досвіду запровадження бойової армійської системи як комплексної системи підготовки курсантів у закладах вищої військової освіти. Організаційно-методичними вказівками передбачалося внесення змін до освітньо-професійних програм, робочих навчальних планів та інших документів із планування, обліку навчальної, методичної роботи щодо введення навчальної дисципліни «Спеціалізована фізична підготовка» (до кінця 2016-2017 н.р.); здійснення заходів з організації підготовки курсантів ВВНЗ, ВНП ВНЗ (збережено термінологію 2016 року), а також підготовку (підвищення кваліфікації) головних сержантів (старшин) частин та підрозділів Збройних Сил України, що безпосередньо здійснюватимуть підготовку особового складу за системою БАРС (з 2017-2018 н.р.), що передбачало переформатування спортивної бази навчально-тренувальних комплексів спорту [9] тощо.

Зауважимо, що особливу увагу приділяли збільшенню (кількісному і якісному) обсягу спеціальної фізичної підготовки частково за рахунок скорочення загальної фізичної підготовки, що дозволило уникнути витрат додаткового часу, з одного боку, а з іншого - залишити відповідність професійної підготовки курсантів прийнятим державним стандартам. Догічно, що високоякісна підготовка передбачає компдексність та неперервність їі забезпечення, грунтування на розумінні й усвідомленні мети, завдань і механізмів їх реалізації та методично доцільного забезпечення практичної реалізації кваліфікованими викладачами (інструкторами). Основним документом є Збірник нормативів з бойової підготовки (ТП 7-00.11.01) та його похідні.

Оскільки завданнями підготовки за БАРС є «оволодіння військовослужбовцями військово-прикладними навичками спеціалізованої фізичної підготовки відповідного рівня для забезпечення фізичної і психологічної готовності особового складу підрозділу до виконання бойових завдань; формування знань, практичних навичок та методичних умінь інструкторів БАРС з планування та проведення навчально-тренувальних занять за видами підготовки» [2], система підготовки передбачає тактико-спеціадьну підготовку (різноманітні види пересувань (без зброї, зі зброєю, комбінованих пересувань зі зброєю та спорядженням, перекиди, перекати, скрутки тощо); долання перешкод без спеціального спорядження (пересування по вузької опорі на висоті, подолання штучних перешкод (спеціальних смуг)); долання перешкод зі спеціальним спорядженням (дії на спорудах (фасадах будинків) без зброї та зі зброєю, спуски та підйоми, наведення переправ); стрільба (способи перезаряджання та зміни магазину, стрільба на коротких відстанях, стрільба під час пересування після фізичних навантажень із різних положень); рукопашну підготовку (компоненти ударної техніки та самострахування (стійки та пересування, прийоми самострахування, техніка ударів руками та ногами, техніка серій ударів та комбінованих ударів); спеціальні прийоми та дії (кидки, захоплення, больові прийоми та контрдії, зв'язування та конвоювання, метання ножів та гранат); прийоми зі зброєю (відбір автомата, пістолета та інших засобів нападу)) та додаткові компоненти (опанування спеціадьними навичками тактичної медицини (овододіння 
прийомами наближення до пораненого (із застосуванням техніки пересування), транспортування пораненого у сектор укриття різними способами); виховання психологічної готовності до дій в умовах бойових обставин; формування методичних навичок і умінь 3 організації й проведення навчально-тренувальних занять за БАРС з особовим складом). Наголосимо, що якісна підготовка курсантів за бойовою армійською системою $є$ можливою дише за умови проведення занять висококваліфікованими фахівцями та 3 достатнім устаткуванням i умовами для відпрацювання відповідних дій.

Зауважимо, що карантинні обмеження, 3 якими стикнулась і система вищої військової освіти, внесли певні корективи у процес професійної підготовки курсантів, проте, на відміну від цивільних закладів вищої освіти, освітній процес не було переорієнтовано на виключно дистанційний формат. Що особливо важдиво в умах, коли країна вже шість років знаходиться в стані постійних військових дій (так званий фактор Російської Федерації).

Розроблена для Сухопутних військ (Звіт про проведення експерименту «Апробація бойової армійської системи (БАРС) під час проведення занять по програмі загальновійськової базової підготовки») та Сил спеціальних операцій / Високомобільних десантних військ Збройних Сия України бойова армійська система після певного етапу апробації була адаптована і для Повітряних i Військово-Морських Сил. 3 метою підготовки військовослужбовців за БАРС (які у подальшому могли 3 бути інструкторами) з урахуванням фізичної, психологічної підготовленості, педагогічних здібностей було відпрацьовано професійні стандарти і освітньо-професійні програми підготовки у вищих військових закладах освіти, навчальних центрах та програми бойової підготовки (2016-2017рр.) відповідно до специфіки підготовки фахівців [9].

Авторськими є Пропозиції щодо організації проведення навчально-методичних зборів (курсів) 3 підготовки інструкторів за бойовою армійською системою (БАРС) (відповідно до тогочасної посади Начальник управдіння фізичної підготовки Центрального управління підготовки та повсякденної діяльності військ (сил) Збройних Сия України).

Щодо підготовки військових моряків зазначимо, що впровадження у їх фахову підготовку бойової армійської системи не зменшує специфічні практико-орієнтовані дисципліни, а передбачає частково структурне переформатування спеціальної фізичної підготовки з метою забезпечення реалізації усіх складових (тактичну підготовку, вогневу підготовку, фізичну (загальну і спеціальну) підготовку і тактичну медицину). Тим паче, що Програмою «Військовий моряк - 2035 професійність і компетентність» [10] передбачено значущу роль «фізичного компонента бойового потенціала» як засобу ведення збройної боротьби, а Стратегією Військово-Морських Сил Збройних Сил України 2035 [11] - досягнення високого рівня сумісності з підрозділами Альянсу для збільшення ефективності при виконанні завдань за призначенням.

Підготовка офіцерів тактичного рівня Військово-Морських Сил Збройних Сил України здійснюється за професійними програмами, затвердженими Генерадьним Штабом Збройних Сил України та державними стандартами вищої освіти, затвердженими Міністерством освіти і науки України (спеціальність 254 Забезпечення військ (сил): стандарти підготовки бакалаврів і магістрів затверджено наказами МОНУ від 12.12.2018 № 1385 та від 30.04.2020 № 582 відповідно; спеціальність 255 Озброєння та військова техніка: стандарти підготовки бакалаврів і магістрів затверджено наказами МОНУ від 05.12.2018 № 1341 та від, 30.04.2020 № 583 відповідно).

Стандартами 2020 року означено, що за окресленими спеціальностями в магістратурі може здійснюватися підготовка не дише офіцерів тактичного, а й оперативного рівня. Необхідність посиленої спеціальної фізичної підготовки курсантів, у тому числі і за бойовою армійською системою, визначається змістом спеціальних компетентностей, зокрема: «здатність розв'язувати складні задачі 
і проблеми професійної діяльності з урахуванням потреб забезпечення національної безпеки та оборони держави; здатність організовувати та керувати бойовою підготовкою підрозділів, здійснювати контродь за іiі ходом; здатність підтримувати належний рівень здоров'я та фізичної працездатності, управляти процесом фізичного вдосконалення особового складу підпорядкованих підрозділів та військових частин; здатність розв'язувати складні задачі забезпечення військ (сил) під час підготовки і ведення операції угруповань військ (сил)» [7; 8]. Стандартами 2018 року окреслено такі спеціальні компетентності: «здатність планувати, організовувати і вести бій підрозділом (за видами, родами Збройних Сил України, інших військових формувань, утворених відповідно до законів України); здатність працювати автономно та в команді (включаючи навички дідерства), виконуючи посадові обов'язки в ході повсякденної діяльності та бойового застосування підрозділу забезпечення (за видами, родами Збройних Сил України, інших військових формувань, утворених відповідно до законів України); здатність переносити тривалі різнопланові фізичні навантаження; здатність розв'язувати спеціалізовані задачі за напрямом професійної діяльності; здатність виконувати функціональні обов' язки в ході навчальної та бойової діяльності підрозділу» [5; 6]. Зазначені компетентності та обумовлені ними результати навчання обумовдюють необхідність спеціальної фізичної підготовки, здійснюваної за ефективними методиками і системами із забезпеченням високого рівня боєздатності військ і сил, чому сприятиме й складові та напрями бойової армійської системи.

Висновки. Високоякісна підготовка офіцерів тактичного рівня ВійськовоМорських Сил передбачає комплексність та неперервність їі забезпечення, грунтування на розумінні й усвідомленні мети, завдань і механізмів їх реалізації та методично доцільного забезпечення практичної реалізації кваліфікованими викладачами (інструкторами) з урахуванням положень аналітичних звітів щодо позитивів і недоліків упровадження бойової армійської системи та відповідно до унормовуючих документів. Перспективу подальших досліджень убачаємо в окресленні особливостей впровадження бойової армійської системи у процес професійної підготовки майбутніх військових моряків.

\section{Список використаних джерел:}

1. Базові положення та елементи основних видів підготовки за Бойовою армійською системою (БАрС). Частина 1 / за редакцією І.С. Овчарука. Одеса : Військова академія, 2016. 122 с.

2. Методичні рекомендації з використання елементів Бойової армійської системи (БАРС) на заняттях з вогневої, тактичної, фізичної підготовки та тактичної медицини / за заг. ред. І. С. Овчарука. Одеса : Військова академія, 2019. 118 с.

3. Методичні рекомендації 3 організації підготовки військовосдужбовців за Бойовою армійською системою. Одеса, 2020. 165 с.

4. Наказ Генерального Штабу Збройних Сил України «Про організацію фізичної підготовки у Збройних Силах України в 2020 навчальному році» № 468 від 13.12.2019 р. Київ, 2019.

5. Наказ МОНУ від 12.12.2018 № 1385 Про затвердження стандарту вищої освіти за спеціальністю 254 «Забезпечення військ (сил)» дия другого першого (бакалаврського) рівня вищої освіти. URL: https://mon.gov.ua/storage/app/media/vishchaosvita/zatverdzeni\%20standarty/12/21/254-zabezpechennya-viysk-sil-bakalavr.pdf

6. Наказ МОНУ від 05.12.2018 № 1341 Про затвердження стандарту вищої освіти за спеціальністю 255 «Озброєння та військова техніка» для першого (бакалаврського) рівня вищої освіти. URL: https://mon.gov.ua/storage/app/media/vishchaosvita/zatverdzeni\%20standarty/12/21/255-ozbroennya-ta-viyskova-tekhnika-bakalavr.pdf

7. Наказ МОНУ від 30.04 .2020 № 582 Про затвердження стандарту вищої освіти за спеціальністю 254 «Забезпечення військ (сил)» для другого (магістерського) рівня вищої освіти. URL: https://mon.gov.ua/storage/app/media/vyshcha/standarty/2020/05/2020-zatverdstandart-254-m.pdf

8. Наказ МОНУ від 30.04.2020 № 583 Про затвердження стандарту вищої освіти за спеціальністю 255 «Озброєння та військова техніка» для другого (магістерського) рівня 
вищої освіти. URL : https://mon.gov.ua/storage/app/media/vyshcha/standarty/2020/05/2020zatverd-standart-255-m.pdf

9. Організаційно-методичні вказівки 3 впровадження бойової армійської системи (БАРС) в загальну систему підготовки Збройних Сия України. Київ, 2016.

10. Програма «Військовий моряк - 2035». URL : https://navy.mil.gov.ua/prezentatsiya-programyvijskovyj-moryak-2035/

11. Стратегія Військово-Морських Сил Збройних Сил Україні 2035. URL : https://navy.mil.gov.ua/strategiya-vijskovo-morskyh-syl-zbrojnyh-syl-ukrayiny-2035/

\section{References:}

1. Ovcharuk, I. S. (Ed.). (2016). Bazovi polozhennia ta elementy osnovnykh vydiv pidhotovky za Boiovoiu armiiskoiu systemoiu (BArS) [Basic positions and elements of basic types of preparation for the military army system]. Odesa: Viiskova akademiia [in Ukrainian].

2. Ovcharuk, I. S. (Ed.). (2019). Metodychni rekomendatsii z vykorystannia elementiv Boiovoi armiiskoi systemy (BARS) na zaniattiakh z vohnevoi, taktychnoi, fizychnoi pidhotovky ta taktychnoi medytsyny [Methodical recommendations on the use of elements of the combat army system (BARS) on agricultural classes, tactical, physical training and tactical medicine]. Odesa: Viiskova akademiia [in Ukrainian].

3. Metodychni rekomendatsii $\mathrm{z}$ orhanizatsii pidhotovky viiskovosluzhbovtsiv za Boiovoiu armiiskoiu systemoiu [Methodical recommendations on the organization of preparation of military personnel by the military army system]. (2020). Odesa [in Ukrainian].

4. Order of the General Staff of the Armed Forces of Ukraine "On the organization of physical training in the Armed Forces of Ukraine in the 2020 academic year" dated December 13, 2019 No. 468. (2019). Kyiv [in Ukrainian].

5. Order of the Ministry of Education and Science dated December 12, 2018 No. 1385 On the approval of the standard of higher education in the major 254 "Ensuring troops (forces)" for the first (bachelor's) level of higher education. (2018). Retrieved from https://mon.gov.ua/storage/app/media/vishcha-osvita/zatverdzeni\%20standarty/12/21/254zabezpechennya-viysk-sil-bakalavr.pdf [in Ukrainian].

6. Order of the Ministry of Education and Science dated December 05, 2018 No. 1341 On approval of a standard of higher education in the major 255 "Arms and military equipment" for the first (bachelor's) level of higher education]. Retrieved from https://mon.gov.ua/storage/app/media/vishcha-osvita/zatverdzeni\%20standarty/12/21/255ozbroennya-ta-viyskova-tekhnika-bakalavr.pdf [in Ukrainian].

7. Order of the Ministry of Education and Science dated April 30, 2010 No. 582 On Approval of the Standard of Higher Education in the major 254 "Ensuring troops (forces)" for the second (master's) level of higher education]. Retrieved from https://mon.gov.ua/storage/app/media/vyshcha/standarty/2020/05/2020-zatverd-standart-254m.pdf [in Ukrainian].

8. Order of the Ministry of Education and Science dated April 30, 2010 No. 583 On Approval of the Standard of Higher Education in the major 255 "Arms and Military Technology" for the second (master's) level of higher education]. Retrieved from https://mon.gov.ua/storage/app/media/vyshcha/standarty/2020/05/2020-zatverd-standart-255m.pdf [in Ukrainian].

9. Orhanizatsiino-metodychni vkazivky $\mathrm{z}$ vprovadzhennia boiovoi armiiskoi systemy (BARS) v zahalnu systemu pidhotovky Zbroinykh Syl Ukrainy [Organizational and methodological guidelines for the implementation of the military army system (BARS) in the general system of preparing the Armed Forces of Ukraine]. (2016). Kyiv [in Ukrainian].

10. Prohrama «Viiskovyi moriak - 2035». [The program "Military sailor - 2035"]. Retrieved from https://navy.mil.gov.ua/prezentatsiya-programy-viiskovyi-moryak-2035/ [in Ukrainian].

11. Stratehiia Viiskovo-Morskykh Syl Zbroinykh Syl Ukraini 2035. [Navy Strategy of the Armed Forces of Ukraine 2035]. Retrieved from https://navy.mil.gov.ua/strategiya-vijskovo-morskyh-sylzbrojnyh-syl-ukrayiny-2035/[in Ukrainian]. 
Chernyavsky O. A.,

REGULATORY AND LEGAL PROVISION OF FUTURE NAVAL OFFICERS' orcid.org/0000-0002-9647-2066

\section{PROFESSIONAL TRAINING BY MEANS OF THE COMBAT ARMY SYSTEM}

The article states that the cadets' professional training is being constantly reformatted in order to ensure their effective actions (combat activity) in extreme environmental conditions, considering significant physical and psychological stress, increasing fatigue, and other adverse factors of combat activity. The main regulations of the Temporary provisions on physical training in the Armed Forces of Ukraine; annual directives of the General Staff of the Armed Forces of Ukraine and relevant orders of the General Staff of the Armed Forces of Ukraine play a leading role in the organization of highquality training of cadets for professional activity by means of the combat army system. The combat army system provides tactical, fire, physical (general and special) training, and tactical medicine.

The purpose of the article is to outline the main provisions governing the introduction of the combat army system in the process of future Naval officers' professional training at higher military education institutions of Ukraine. The research methodology consists of the main provisions of the cognitive theory and such approaches as acmeological, task, activity, and complementary methods, in particular, content analysis, generalization, the study of documentation. The scientific novelty of the study consists in outlining the regulatory and legal framework for the introduction of the combat army system in the future officers' training.

It is concluded that high-quality training of the officers of the tactical level of the Naval forces provides the complexity and continuity of its provision, based on understanding and awareness of the purpose, tasks, and mechanisms of their implementation and methodologically appropriate provision of practical introduction by qualified teachers (instructors), taking into account the provisions of analytical reports on the positive sides and drawbacks of the combat army system and in accordance with the regulations.

Key words: naval forces; Armed Forces of Ukraine; future officers; professional training; combat army system.

Дата надходження статті: 11.01.2021 p.

Рецензент: доктор педагогічних наук, професор Міненок А. О.

У,К 37.091.12:005.963

DOI https://doi.org/10.37915/pa.vi48.221

Юзбашева Г. С., orcid.org/0000-0003-3714-1125

\section{ПРОФЕСІОНАЯІЗМ ПЕДАГОГА - ЗАПОРУКА ЯКОСТІ ОСВІТИ}

У статті проаналізовано чинники підвищення якості освіти.

Одним із головних аспектів післядипломної педагогічної освіти є курси підвищення кваліфікації. Наголошено, що зміни в післядипломній освіті будуються на принципах відкритості, неперервності, мобільності в таких основних дидактичних складниках освітнього проиесу, як: зміст, технологї, методи, форми.

Зміст представлено у поєднані навчальних дисцииплін, які формують цілісне уявлення особистості про природу та эï явища. Інтеграція змісту підвищуе інтерес освітян до досліджень та сприяе розвитку їхнього наукового мислення.

Педагогічні технологї доповнюють навчальне середовище освітнього процесу післядипломної освіти. Використання різноманітних технологій збільщуе інтерес у педагогів до організації та планування власної діяльності.

*(C) Юзбашева Г. С.

بs 178 